\title{
A NEPOTISM AND CRONY IN A BUSINESS, CASE OF INDUSTRIAL DEREGULATION IN INDONESIA
}

\author{
Muhadjir Efendy \\ Universitas Muhammadiyah Malang \\ Jalan Raya Tlogomas No. 246 Malang - Jawa Timur 65144
}

Diterima 25 Nopember 2010/Disetujui 15 April 2011

\begin{abstract}
An industrial deregulation is a government policy in developing a state's economic infrastructure. If a country undergoes a process of powerful personalization, its interest is identical with a powerful interest. For an economic profit, the President's relative and crony do a business and build directly unproductive seeking activities. This study aims to examine the relation of relative to crony in realizing an industrial deregulation in the 1980s and its impact on the Indonesian economy in a view of macroeconomic policy. It focuses on a problem of the industrial deregulation from 1983 to 1990 with economic growth by the indicator of contribution to GDP and labor force. The study used an expose facto approach. The data were the secondary sources: documents, textbooks and mass media. It used a qualitative-descriptive analysis.
\end{abstract}

Keywords: nepotism, industrial deregulation, crony in business, economic bankruptcy

\begin{abstract}
Abstrak: Deregulasi industri merupakan kebijakan pemerintah dalam membangun infrastruktur perekonomian negara. Manakala negara mengalami proses personalisasi kekuasaan, ketika itulah kepentingan negara nyaris identik dengan kepentingan penguasa. Kepentingan ekonomi yang berlanjut dengan keterlibatan kerabat dan teman dekat presiden ke dalam dunia bisnis, menyuburkan praktek directly unproductive profit seeking activities, yakni aktivitas yang mengarah pada mencari keuntungan tanpa usaha produktif. Tujuan penulisan ini untuk mengungkapkan awal mula praktek hubungan perkerabatan dan perkoncoan dalam pelaksanaan deregulasi industri pada tahun 1980-an dan dampaknya terhadap perekonomian Indonesia ditinjau dari sudut macro economic policy. Tujuan tersebut disederhanakan dengan fokus mengenai persoalan deregulasi industri antara tahun 1983-1990 terhadap pertumbuhan ekonomi dengan indikator kontribusi terhadap GDP dan penyerapan tenaga kerja. Penelitian ini menggunakan pendekatan penelitian exspose facto. Data diperoleh dan dikumpulkan dari sumber-sumber sekunder yaitu buku-buku bacaan, dokumen-dokumen dan penerbitan mass media oleh sebab itu penelitian ini tergolong penelitian leterer. Alat analisis data yang digunakan analisis diskriptif kualitatif.
\end{abstract}

Kata kunci: nepotisme, deregulasi industri, kroni bisnis, kebangkrutan ekonomi

\section{INTRODUCTION}

In a very optimistic sense and due to the praise of various world institutions, the government of the New Order (1966-1997) was very ambitious to be parallel with the group of the new industrialized countries in Asian area; and ultimately, it would be a country with a new giant economy. It is noted that the new industrialized countries were South Korea, Taiwan, Hong Kong and Singapore (Mustafa Dakian, 2005: 2).

To complete that, the government of the New Order designed a framework that reflected a sequence of the actions. This article will present an evident analysis that leads to a conclusion: between the economic-politic blue 
print and its implementation had conically distorted. The event focused on the second decade (in the 1980s). In line with launching an industrial deregulation policy, the distortion was in a very serious happening. In the next years, it was more and more increasingly serious so that the ambition could not was totally reached because of economic crisis in the 1990s.

Since the development acceleration and modernization in Indonesia in the 1970s, an industrial sector quickly shifted other sectors, particularly agriculture, to contribute to national income. To reach the ambition, the era of Soeharto government had deregulated in an industrial sector since 1983. In the early, its process seemed positive (Muhamad Hisyam, 2003: 229). One of the indicators was the Indonesian economic growth in the late 1980 on the average of the developed countries' (Muhamad Hisyam, 2003: 229).

The deregulation could not be free from the framework of the New Order development ideology that essentially used three approaches: political order approach, economic technocratic approach, and dependency approach (Robison, 1990: 32-33). The political order approach results in a high effort to emphasize the factors in political stability rather than other stabilities such as economic when launching an industrial deregulation. Therefore, the government plays a very high role in it

When the country undergoes process of powerful personalization, its interest is nearly identical with the powerful one, i.e., the President Soeharto (Fatah, 2004: 335). Similarly, in the economic field, the nepotism and 'crony' of the President Soeharto developed in a business and even participated centrally in taking a decision. As a result, an industrial deregulation was subject to a business of nepotism and crony.

The economic technocratic approach tends to use the integration of neoclassical-interventionist school where it is very oriented to market on one side and the government tends to regulate it on the other side. The dependency approach makes an industrial policy depend on capital, professional worker, raw material and foreign market.

The distortion in employing the approaches makes an industrial deregulation be- ginning in the 1980s took place. An effort for increasing efficiency by developing a largesized industry will merely develop directly unproductive profit seeking activities.

The activities can probably be done through crony and nepotism. If so, who has an opportunity? In the system of the New Order government, the executive (the President), the President's family, his business counterparts such as the Chinese offspring had distorted the policy.

The business counterparts had been a crony since the era of the Independence war. They had financially and logistically supported to General Soeharto and his troops so that the relation between them could be said to be 'gratitude.' Two of the influential Chinese counterparts, for example, were Liem Sioe Liong who possessed 350 firms in 1989 and Kian Seng (Bob Hasan) who possessed 110 firms (Mallarangeng, 2008: 190).

The distortion of the industrial deregulation policy seemed paradoxical when the monopolistic and oligopolistic markets and protectionism policy in domestic industry was unreasonable. Then, the protectionism policy resulted in 'channels' that caused a 'businessman' who takes an uncompetitive profit of the Toll Gate Business to be able to run more flexibly through the connection of the politic elites, particularly through the Family of Cendana. ${ }^{1}$

Ultimately, it is historically proved that the practice of the 1980s negative externality of industrial deregulation had significantly caused the Indonesian economic fall in the late 1990s and forced the President Soeharto to retire his post on May 1998. ${ }^{2}$

Referring to the problem above, this article will describe a practice of the relationship between nepotism and crony in realizing an industrial deregulation in the 1980s and its impact on the Indonesian economy in a view of macroeconomic policy. In a sociological perspective, however, it emphasizes micro sociology rather

\footnotetext{
1 The Cendana's family is a term referring to the name of street where the President Soeharto lived.

2 Adi Sasono, an Interview with Adi Sasono (liem Siok Lan), Siok Lan Liem. 2008, Leading to people in sovereignty: an Interview with Adi Sasono, the Head of the Indonesian Cooperation. Jakarta: Penerbit Republika, p. 54.
} 
than macro sociology. The micro sociology can be defined as sociology that studies a variety of thinking ways and behavior of the small groups (Liliweri, 2005: 152). The micro sociology studies a decision-making process, integration of nepotism groups, and influence of a group's member on his or her insight of environment.

In the Indonesian micro sociology, the relationship of nepotism to crony has not been actualized yet. It is different from other studies such as the relation of patron-to-client, patrimonial and bureaucratic politic.

Nepotism and crony that have become into being since the 1997 reformation era are a public discourse (Budi Winarno, 2007: 52) although it has existed since the Soeharto government era and even before the era. The practice of nepotism has begun since the 1970s when Soeharto's children, relative and his friends' children have been adults. Then, they have done a business and become a member of Golkar (the Group of Functionaries, a political party established by government for technocrats and civil servants) (Junaidi Muadzin, 2009: 4).

This study examined a problem of the 1983-to-1990 industrial deregulation. It used an expose facto approach. The data were the secondary sources: documents, textbooks and mass media. It used a qualitative-descriptive analysis.

\section{DISCUSSION}

\section{An Industrial Sector: Analysis Of Macro- economic Policy}

Since the 1970s, one of the indicators for economic development successfulness has been economic transformation dominated by an industrial sector. It can be seen from its contribution to GDP, labor force, and economic growth. ${ }^{3}$

The schools for an industrial sector development are neoclassical and interventionist.

\footnotetext{
3 The discussion on economic transformation can be seen in Chenery, 1960, "Pattern of Industrial Growth, American Economic Review". Vol. 50, pp.624-654. By using a crosssection scale, found that an increasing higher a country's income per capita, an increasing greater its industrial sector in a view of the contribution to GDP and economic growth, and labor force.
}

The neoclassical school is an incentive-centralized trade, not distinguishing a domestic market from international one. It believes that by applying an incentive-centralized trade, a productive resource will penetrate economic sectors with a high international competition.

The essential assumptions include: (1) a market will work efficiently and government intervention always decreases welfare; (2) resource allocation will be optimal if the 'businessman' think about a market rule; and (3) government intervention is not needed so that a market will work well.

In an industrial sector development, this school is supported by macroeconomic reality, an import substitution strategy tends anti-export, and a manufacturing firm does not accept goods export because a domestic market can result in high profit.

In the interventionist school, intervention is needed to change a country's comparative advantage. This school states that an industrial policy is neutral. It is an effective way of shifting an industrial structure to a more sophisticated industry that can generally result in advantage and efficiency through a "learning process." 4

The successfulness of the new industrial countries in the firstier East Asian NIES (South Korea, Taiwan, Hong Kong and Singapore) in industrial sector development is intended to lead to a debate between the two schools.

The neoclassical school suggests that the successfulness is due to open policy and neutral incentive; whereas the interventionist states that it is the intervention that encourages an industrialization process so that it generally needs a 'no-neutral' incentive. This intervention is needed because a market does often not work efficiently and it causes a market failure.

The industrial policies of South Korea, Taiwan, Hong Kong and Singapore are generally categorized as an efficient-selective policy. The intervention is oriented to overcome a market failure. To support an industrialization

\footnotetext{
4 The debate on economics school in Indonesia can be seen in Keynes or Friedman or both: An Essay in Macroeconomic Theory for Indonesia's in "The Indonesia Economy Collected Papers", Chapmen Publisher, Canberra, 1996, pp. 21222.
} 
Table 1. A Classification of Trade Orientation-Based Economic Development and Rate of Income Per Capita in 1980

\begin{tabular}{clc}
\hline Outside-Trade Orientation & \multicolumn{1}{c}{ Countries } & Income Per Capita \\
\hline High & Hong Kong & 4,240 \\
& Singapore & 4,430 \\
& Korea Selatan & 4,520 \\
\multirow{2}{*}{ Medium } & Malaysia & 1,620 \\
& Thailand & 670 \\
Low & Indonesia & 430 \\
& Philippine & 450 \\
\hline
\end{tabular}

Source: Dodaro, 1991.p. 1154

Table 2. A Change in GDP Structure in the 1975-1990 ASEAN Countries

\begin{tabular}{cccccc}
\hline Countries & Years & $\begin{array}{c}\text { Agricultural } \\
\text { Sector }\end{array}$ & All Sectors & $\begin{array}{c}\text { Manufacturing } \\
\text { Industry }\end{array}$ & $\begin{array}{c}\text { Service } \\
\text { Sector }\end{array}$ \\
\hline Indonesia & 1975 & 36,8 & 27,2 & 11,1 & 35,9 \\
& 1985 & 22,7 & 39,7 & 15,8 & 37,6 \\
Malaysia & 1990 & 19,6 & 40,9 & 19,3 & 39,5 \\
& 1975 & 27,7 & 26,8 & 16,4 & 45,5 \\
Philippine & 1985 & 20,8 & 36,7 & 19,7 & 42,6 \\
& 1990 & 18,7 & 42,2 & 26,9 & 39,0 \\
Singapore & 1975 & 26,8 & 34,1 & 28,3 & 39,1 \\
& 1985 & 24,6 & 35,1 & 25,2 & 40,4 \\
Thailand & 1990 & 22,5 & 35,8 & 25,4 & 41,7 \\
& 1975 & 1,5 & 37,2 & 26,0 & 61,3 \\
& 1985 & 0,8 & 36,6 & 23,6 & 62,6 \\
& 1990 & 0,3 & 36,6 & 29,0 & 63,1 \\
& 1975 & 24,8 & 27,3 & 19,9 & 47,9 \\
\hline
\end{tabular}

Source: Asian Development Bank, in, 1993. p. 133

process, for instance, it needs to develop a technique and training for firm employees to produce internationally-competitive-high technology goods. It is assumed that it is a reason the countries' economy is highly oriented to outside and their income per capita is higher than the other Asian countries. 5

The incomes per capita of South Korea, Taiwan, Hong Kong and Singapore in 1980 reached over US $\$ 4,000$. The incomes per capita of Malaysia and Thailand were US $\$ 1,620$ and US $\$ 670$ and those of Indonesia and Philippine were US \$430 and US $\$ 450$ (see Table 1).

The successfulness of the Firstier East

5 Dodaro's Analysis, 1991, 'Comparative Advantage, Trade and Growth: Export-led Growth Revised', World Development. Vol. 18 No. 9 pp. $1153-1165$ states that there is a high correlation of economic growth and industrial manufacturing proportion.
Asian NIES had inspired Malaysia and Indonesia to be the second-tier East Asian NIES. In the industrialization field, Malaysia encouraged manufacturing and chemical industries and Indonesia leapfrogged from 'more manual labor' industry to high technology one, for example airplane industry. Unfortunately, however, the 1990 economic crisis caused the ambitious industrialization program not to be able to run smoothly.

In a historical view of the 1975-1990 economic transformation of the ASEAN countries, it had structurally changed significantly. The optimism of the countries to be NIEs was supported by the contribution data of industrial sector to increasingly higher GDP (see Table 2).

In Table 2, a change in the Indonesian economic structure was very fast. The rate of manufacturing industrial growth rose sharply. 
Table 3. The Rate of Effective Protection for the 1980-1995 Indonesian Economic Sectors

\begin{tabular}{clcccc}
\hline No. & \multicolumn{1}{c}{ Economic Sectors } & $\mathbf{1 9 8 4}$ & $\mathbf{1 9 9 0}$ & $\mathbf{1 9 9 2}$ & $\mathbf{1 9 9 5}$ \\
\hline A. & Agricultural Sector & & & & \\
& 1. Food Plant & 18 & 20 & 20 & 15 \\
& 2. Plantation & 14 & 12 & 13 & -1 \\
& 3. Animal Husbandry & 33 & 31 & 29 & 17 \\
& 4. Forestry & -20 & -43 & -43 & -53 \\
& 5. Fishery & 15 & 16 & 15 & 27 \\
B. & Mining & -1 & -1 & -1 & 3 \\
& 1. Oil-gas & 0 & 1 & 1 & 3 \\
C. Non oil-gas & Industry & 152 & 139 & 82 & 53 \\
\hline
\end{tabular}

Source: Fane, 1996

In 1975, it reached 11 percent and in 1990, it reached 19.3 percent of GDP. Malaysia and Thailand kept a growth rate of 8 percent per year and an economic growth of Philippine was about 0.5 percent per year. The GDP of Singapore was dominated by manufacturing and services sectors.

The growth of industrial sector decided a protection policy from year to year. The rate of effective protection by government can be seen in Table 3.

From Table 3, among the sectors, the manufacturing industrial sector got the highest protection while the sectors with a negative sign such as forestry got some subsidy. The value of the forestry effective protection was negative because this sector subsidized a plywood industry sector. The high industrial sector protection indicates that Indonesia has an economic policy focusing its economy on the industrial sector.

The government's protection generally is intended for a large-sized industry with capital intensive and skilled workers through outputand input-cost subsidy, tariff, and monopoly power. ${ }^{6}$ Based on the level of employment provided by each economic sector, however, the job vacancy of this sector is very small. The Statistic Center Bureau reported that this sector only resulted 9.3 percent in 1985 and 11.4 in 1990. Nevertheless, the policy remained to lead

\footnotetext{
6 The discussion of the government's protection role in an industrial sector can be seen in Das (1998), Dodaro (1991), Kreinin and Plummer (1992), and Dean (1995). The earlystage protection of industrialization is needed to improve a growing-industrial sector, or often referred as argument infant industry.
}

to an industrial development although other sectors got a loss. More credits were allocated to this sector that other sectors. Furthermore, the industry with accessibility to foreign credit uses some credit distributed by government.

The large employers (about 20 people) dominated 74.70 percent of the credits distributed by the government. The large differences between domestic interest rate to foreign interest rate was incentive for private sectors to expand their business with excessively-marked up warrant. Today, the value of rupiah exchange rate in US dollar is relatively low so that many people do an advantageous speculation practice. But, when the rupiah value is depreciated, gain from the margin of this interest rate can't compensate a loss. ${ }^{7}$ The self-financing and provision of credits in large number to personally-owned firms increase more private debts. The privately-owned firms that do not pay for their debts, particularly in US dollar, make foreign debts be a domestic economy burden.

\footnotetext{
7 An exchange rate fluctuation impact on a price and macroeconomic activity was discussed by Papell (1994). A discussion of the cost and benefit of dollar use for paying an international trade was discussed by Schuler (1999). An international interest rate ranged from $5 \%$ to $6 \%$ per year, but a credit interest rate in Indonesia ranged from 12\% to $35 \%$. Similarly, the bank and financial deregulations made the condition increasingly worse. Many industrial sector businessmen established a bank and did self financing, for example, Liem Sio Liong, Sjamsul Nursalim, Eka Tipta Wijaya, Bambang Trihatmojo, and Boh Basan established BCA, BDNI, BII, Andromeda Bank, BUN etc., respectively. These banks distributed credits to the industrial sector firms. By operating a floating exchange rate, a gain of domestic-foreign interest rate was lower than a loss causing rupiah depreciation.
} 


\section{A Relation of Nepotism to Crony in the Industrial Deregulation in the 1980s}

As described above, the practice of nepotism and crony in a business is a kind of corruption because of the powerful personalization of state, mainly the presidential post more frequently causing a negative and inefficient externality. The focus of the problem is on discussing partially. However, this partial analysis can comprehensively be expected to describe what the practice of nepotism and crony took place in relation to the industrial deregulation policy in the 1980s.

Partially, this article discusses a light industry, import regulation, mainly raw materials, plastic-raw materials monopoly, steel control and distribution. For discussing these aspects, we used as main sources including such textbooks as Managing Indonesia: the Modern Political Economy by John Bresnan (Columbia University Press, 1993) and The Economy in Indonesia New Order: the Dynamics of Socioeconomic Transformation by Hall Hill (Allen \& Unwin, 1994).

Light Industrial Sub-Sector. In the beginning in the 1970s, John Bresnan stated that the Indonesian manufacturing sector was dominated by the factories producing consumption goods (foods, beverages, tobaccos and textiles in particular) that were competitive in the economic crisis.

In ten years later, the factories with large capitals were more competitive than those with small capitals. According to Hall Hill (1994), it is common in a majority of developed countries to lead to industrialized countries. It is mainly due to a very fast domestic market growth and the ambition of the countries to 'find' international market share for raising their exports. The factories with large capitals produced fertilizer, pharmacy, vehicle, electronic and plywood.

Unfortunately, in 1982 the domestic market for the products highly decreased. Consequently, the program was intended to protect how the factories did not go bankruptcy. For this reason, it is necessary to take protection economic policies, including (1) a campaign for using domestic products, (2) very strict import control, and (3) new investment increasing.
In the late 1980s, because of a change in a foreign exchange rate, to meet a short-run supply, a government's policy was intended to (1) give a large chance of financial service business by involving domestic and foreign businesses, (2) 'alleviate' control for a large number of import manufacturing products, and (3) facilitate foreign investments. All did not happen in 1974. As a result, in the beginning of 1990, the investment, export volume and government's income rose very fast.

The action taking by the government resulted in a regulation process that was particularly intended to take a protection action on one side and a deregulation process that was intended to accelerate a performance of expanding an industrial sector on the other side.

However, the processes were a portrait of interest conflict in power for the officials consisting of families and their business cronies. It caused a debate of (1) public sector in the future, (2) dominant business groups of Chinese offspring in the private sector, and (3) better positions for the President's families, close relatives and business cronies. 8

Import Regulation. Rice import has been monopolized by Bulog (Logistic Agency), stateowned agency since the early of New Order government. In the years later, it also imports other food products.

The import of manufacturing products was limited, such as vehicles, to protect a domestic manufacturing industry. Other products that could be imported the Holding Company having a license of Industry and Trade Ministry were raw materials needed for a production process.

The system of new trade was introduced in 1982. This sets a list of raw materials component and product that could be imported by agencies. These were agricultural products such as cotton, flour, milk, crop in dry season, clove and sugar. In the forthcoming time, it also permits to import such products as iron, steel, plastic, chemical, textile, paint, rubber, paper, glass, vehicle and machine.

\footnotetext{
8 The Grand Son Also Rises by Hans Vriens in Journal Asia, Inc, edition Marc 1995. In his work, Vreins stated that the President Soeharto's family can only be competitive with Sultan Brunei in building the richest family's business dynasty throughout the world.
} 
In the beginning of 1986, the import license controlled 1,484 kinds of products (goods). Among 1,360 manufacturing products, 296 products were imported. The products valued US $\$ 2.7$, a half of total import (Bresnan, 1993: 247).

An import license is not occasionally based on import trade whereas other licenses are based on specific types and products in number. But, the other license is determined by its import agency. The trade order is frequently conducted by state-owned agencies and private-owned companies. Some state-owned companies (for example, PT Krakatau Steel) responsible for controlling products and their users are in charge of controlling 82 kinds of steel and iron.

Briefly, economy was strongly protected during the recession in the beginning of 1980s. Some the officials of Economic Ministry did not think about such private sector as a foreign investor who neglected a trade system. But, the Industrial Minister believed a program instructed by the President. There was a great debate of import substitution vs. export promotion. Some members of governmental cabinets did not trust an issue of the export. Unfortunately, however, they did not find any alternative to solve the problem.

Mohammad Sadli, one of the former Ministers of the New Order government, stated that the government set a quota because of GATT (General Agreement on Tariffs and Trades) charging a high tariff and it would result in more losses. The other consideration was a trade system through this import monopoly where a firm could accumulate capital and it is ultimately expected that it could expand to build a factory 'operating' industrial raw materials in the home.

Plastic Raw Material Monopoly. A degree of the Trade Minister on October stated an import of various raw materials for plastic industry was under governmental control. These materials included (1) polyethylene for producing household furnishings made of plastics, (2) polypropylene for producing plastic bags, food packages and the like, (3) polystyrene for plastic glass materials, (4) polyvinyl for producing plastic pipes, and (5) acetate and acrylic.

Those materials were only imported by three state-owned corporations: PT Panca Niaga, PT Cipta Niaga and PT Mega Eltra in which they got any subsidy from the Trade Ministry. Each got the same quota in a ton for a kind of materials (Bresnan, 1993: 248-249). The new policy was intended to assure a survival of operating domestic plastic industry by providing raw materials, particularly imported ones.

The total of the last four raw materials were US \$361 million in 1984. The raw materials of polyethylene and polypropylene reached US $\$ 300$ million. The two could not be produced in Indonesia but the others could. In a joint venture with Japanese firms, Indonesian firms produced polyvinyl and polystyrene. The polystyrene was produce by PT Polychemlindo, one of the firms of PT Bimantara Group owned by the President Soeharto's son.

The decree of the Trade Minister above announced that on March 1985 the three stateowned corporations instructed Panca Ltd, one of the private firms as an agent for all plastic imports, headquartered in Hong Kong, where it was headed by Sudwikatmono, the President Soeharto's crony.

Steve Jones of the Asian Wall Street Journal headquartered in Hong Kong reported that based on the data, the Panca Holding belonged to two firms registered in Vanuatu where the President Soeharto's two sons, Bambang Triatmodjo and Sigit Haryo Yudanto, became a board member of director. ${ }^{9}$

The government charged about US $\$ 23$ per ton while the Panca Holding did US \$20 per ton and it ultimately raised US $\$ 70$ per ton plus 2 percent of transaction value. In 1986, the sale of polyethylene reached US $\$ 500$ per ton. This 'mark-up' was added 21 percent of import cost.

Some executives' survey showed that this system was illogical. Some consumers remain to directly corporate with foreign suppliers and did not use a bureau of governmental trade or with the Panca Holding but they directly met these suppliers.

Nevertheless, it could not run effectively because it took one month before order. The

\footnotetext{
9 A supplier's license developed into a producer thorugh PT Candar Asri finding the protection's government. However, the Financial Minister stated that the supplier would not find a protection.
} 
firms sent goods to the consumers before they received a document. It means to spend more cost for saving.

It is estimated that as a monopoly holder in 1985 the Panca Holding with 'Tollgate business' could gain a profit of US $\$ 30$ million.

On August 1986, when the government announced that the only one state-owned corporation, PT Mega Eltra, that operated a plastic quota and kept the Panca Holding as an agent, the industry was uncompetitive. In the end of profit of US \$20 per ton and a 2.5 percent-cost of the total sales value. Between 1984 and 1985, when the value of imported cold-rolled steel was more than US $\$ 400$ million, the profit of monopoly was nearly the same as that of the plastic sector monopoly.

The director board of PT Giwang Selogam was Liem Sioe Liong, who held a 20 percent share, and its executive director was Sudwikatmoko, the President Soeharto's crony, who held a 6.7 percent share. The other shares were competitive steel price. IVIany decisions made by the officials of Trade Ministry were intended for some firms that served as an agent of PT Krakatau Steel to import and distribute the steels in the home.

On April 1984, PT Giwang Selogam could import cold-rolled steel on behalf of PT Krakatau Steel. In cooperation with PT Krakatau Steel, the company had also had other businesses. PT Krakatau Steel controlled hot-rolled steel in various forms whereas PT Giwang Selogam controlled cold-rolled steel import and a product of PT Krakata Steel's branch beginning to operate in 1987.

This import monopoly could result in a chance in a policy agenda in the Iater. I ne government tries to promote an indigenous businessman through some programs but a private businessman essentially gets less attention from the government and always needs to be instructed in its business activity.

The fourth five-year plan, announced in the early of 1984, began considering this private sector. In the plan, the government expected that the private sector could result in 9 million of new labor forces. Thus, an economic growth must be raised at 5 percent. For this, it needs an investment of Rp142.2 trillion but the government only provided a half of the total investment. So, the private sector must generate an 
investment of Rp67.5 trillion.

Then, who were the private businessmen? The Tempo Magazine, an influential magazine in the era, reported that not all the private sectors could support it. The 'giant' businessmen such as Liem Sioe Liong, William Soeryadjaya, Lie Siong Thay, The Nin King, Sjamsul Nursalim - all of the Chinese offspring - were people who could support it.

A high expectation to develop the indigenous private firms could never be realized after they were unsuccessful in the 1950s through 'Benteng (Castle) program.' Since the era, especially in the President Soeharto's government, the Chinese ethnicity dominated a business and commercial sector. This ethnicity was increasingly stronger. According to Richard Robison, it was due to a reliable and wide family's trade system that built a very well-distributed and credited network in the home and that was related to the Chinese business groups in the area of ASEAN. He also thought that an increasing higher military-political role put a number of the Chinese capitalists into a role as a fund provider and operator for military officers (Robison, 1988: 271-273).

The relation of the government to the Chinese business groups was controversial. The government encouraged the indigenous private businessmen but it cooperated with the Chinese business groups in investments. These investments could be a production cement, flour, chemical, paper, petrochemical, fertilizers, pharmacy, voyage, electrical power, and mining.

It was estimated that one-third of the stated-owned bank loan were dominated by the Chinese business in secret relation to military and civil officials. Besides the Chinese offspring businessmen, of course, there were some indigenous businessmen who were involved in the nepotism; although there were many Chinese businessmen who did their businesses fairly. However, Kwik Kian Gie, a Chinese businessman and the former Head of National Planning Board in the era of Megawati government recognized that among the Chinese businessmen were reasonably fallen into a 'bad conglomerate.'

The history of successful-economic deve- lopment of the New Industrialized Countries in Asia for the first generation, including South Korea, Taiwan, Hong Kong and Singapore, has been discussed by such economists as James, Naya and Meier (1989). One of the lessons, particularly in Taiwan and South Korea, shows that an economic transformation from agriculture to industry needs resources. Its consequence can be more negative if an industrial sector is protected excessively and there takes a place of negative externality. In the operation of industrial deregulation in the 1980s, it seems that the thesis is clear, i.e., the negative externality has taken a place from a policy-making central level to implementation system. The externality begins from a process of state personalization to a nepotism business activity and crony system that are conducted by the President Soeharto's family, relatives and cronies.

In a view of macroeconomic policy and real sectors when the industrial deregulation in the 1980s was enforced, it is proved that the fundamental industrial sector in Indonesia is very 'fragile.' In fact, the large industries grow in foot loose industry, using raw materials and foreign labor force so that it is very intensively import. The large businessmen in the limited amount with access to foreign credit dominated at 74.70 percent of the government's total credit while the rest for small- and middle-sized ones. Many of businesses in the industrial sectors remain to be protected by the government with the argument of an infant industry that finally becomes an old baby industry. Many largesized businesses in the industrial sectors do rent seeking through monopoly. The large businesses by the government's protection with a monopoly are expected to compete in an international market, but they can only be competitive in the home. A drive of large-sized industrial development in de facto highly depends on some large businessmen.

\section{CONCLUSION}

It can be concluded that what the industrial deregulation in the 1980s with all the policies and the practices of crony and nepotism are, it has very highly driven to the Indonesian eco- 
nomic bankruptcy since 1990s. In addition, the deregulation policy has made the President Soeharto topple down. He stepped down his office after 32 years in power, exactly on May 12, 1998. However, many people think that Soeharto is one of the best citizens for Indonesian people, and it seems that he will be the only person who has powered for a long time in the history of presidency of Indonesian Republic.

\section{REFERENCES}

Basri, F., 1995. Perekonomian Indonesia Menjelang Abad XXI. Jakarta: Erlangga.

Chenery, H. B., 1960. Pattern of Industrial Growth. American Economic Review. Vol. 50.

Dakian, Mustafa. 2005 Sistem Kewangan Islam: Instrumen, Mekanisme, dan Pelaksanaannya di Malaysia. Kuala Lumpur, Utusan Publications \& Distributions Sdn Bhd.

Das, D. K., 1998. Changing Comparative Advantage and the Changing Compotition of Asian Export, The World Economy. Vol. 21 No. 1.

Dodaro, S. 1991. Comparative Advantage, Trade and Growth: Export Led Growth Revisted. World Development. vol. 18 No. 9

Fane, G. 1996. The Trade Policy Review of Indonesia. The World Economy, Vol. 19 No. 1.

Hill, H., 1994. The Economy in Indonesia New Order: The Dynamics of Socioeconomic Tranformation, Sidney: Allen \& Unwin.
Hisyam, Muhamad. 2003. Krisis Masa Kini dan Orde Baru. Jakarta: Yayasan Obor.

James, W.E., S. Naya and G.M. Meier. 1989. Asian Development Economic Succes and Policy Lesson. Madison: the University of Wisconsin Press.

Kreinin, M.E. and M.G. Plummer. 1992. Effect of economic Integration in Industrial Countries on ASEAN and the Asian NIEs, World Development. Vol. 20. No. 9.

Lynch, D. 1996. Measuring Financial Sector Development: A study of selected AsiaPacific Countries. The Development Economies, Vol. XXXIV No. 2.

Mallarangeng, Rizal. 2008. Mendobrak Sentralisme Ekonomi: Indonesia, 1986-1992. Jakarta: KPG (the Popular Library of Gramedia) p. 190.

Okada, Y. 1983. The Dilemma of Indonesia Dependency on Foreign Direct Investments, Development and Change, Vol. 14.

Fatah, R. Eep Saefulloh. 2004. Mencintai Indonesia dengan Amal: Refleksi atas Fase Awal Demokratisasi. Jakarta: Republika, 2004, p. 335.

Richard Robison, Indonesia: The Rise of Capital, The Asian Studies Association of Australia, p. 271-273.

Robison, R. 1990. Power and Economy in Suharto's Indonesia. Journal of Contemporary Asia Publisher.

Sanderson, Stephen. 1995. Sosiologi Makro. Jakarta: Raja Grafindo.

Winarno, Budi. 2007. Sistem Politik Indonesia Era Reformasi. Yogyakarta: Medpress. 